\title{
Effects of Introducing Type\&Screen System on Rational Use of Transfusions
}

\author{
Aleksandar O. Stefanović ${ }^{1}$, Emina S. Čolak ${ }^{1}$, Gordana D. Stanojević ${ }^{2}$, \\ Ljubinka I. Nikolić ${ }^{1}$
}

${ }^{1}$ University Clinical Center of Serbia, Belgrade, Serbia

2 Primary Health Center Zvezdara, Belgrade, Serbia

\section{SUMMARY}

Introduction: The number of blood donors at the global level has decreased primarily due to ethical and age-related changes in the structure of the planet's population. In addition, there is over ordering of blood for surgical patients. Accordingly, there is a need for rationalizing the testing i.e. reducing the number of cross-matchings and decrease in the use of blood. A type and screen (T\&S) upon admission is sufficient for most patients. Determination of $A B O$ blood group and Rh type, and screens for clinically significant alloantibodies is denoted as type and screen (T\&S).

Aim: Comparison of pharmaco-economic effect using transfusion indices on the number of performed cross-matches and the amount of packed red blood cells issued.

Material and Methods: The authors present the comparison between the year 2010 before the introduction of the Type and Screen (T\&S) system and the year 2019 when the T\&S system and restrictive policy in transfusion practice, were introduced. Data for 2010 were collected from written transfusion protocols of the clinic, and for 2019 were obtained from the hospital information system (Heliant) and written transfusion protocols. The difference between two groups of data was examine with Chi-square test and Fisher exact test, with the reliability level set at $p<0.05$.

Results: With the introduction of the T\&S system, the number of cross-matches was reduced from 0.63 to 0.49 and the number of blood units was reduced from 0.21 to 0.11 per hospitalized patient, which at the level of one clinic represents a significant pharmacoeconomic contribution of approximately 50\%. In our study, after processing T\&S in ordering of blood, the indices (CTR, \%T, TI) failed to improve. Despite of unsatisfactory transfusion indices, the application of restrictive indication policies in accordance with national and international guidelines has led to highly significant reduction in the consumption of total blood from 3243 to 1867 blood units. The BOQ as an overall assessment of the results after the introduction of the T\&S procedure indicated improvement.

Conclusions: The introduction of validation in blood transfusion indirectly draws the attention of prescribing physicians to take into account the significance of blood therapy. The effects of the introduction of the T\&S method and restrictive transfusion policy are savings in blood consumption, decreased number of patients tested, a significant reduction in used blood units, and the number of performed cross-matches, despite the increased number of patients.

Keywords: Transfusion Indexes, Cross-Match, Blood, Blood Group, BOQ, CTR, TI 


\section{INTRODUCTION}

The number of blood donors at the global level has decreased primarily due to ethical and agerelated changes in the structure of the planet's population. In addition, there is over ordering of blood for surgical patients. Accordingly, there is a need for rationalizing the testing i.e. reducing the number of cross-matching and decrease in the use of blood [1].

Cross-matching may be electronic or serologic. Electronic cross-matching also known as computer cross-matching (E-XM) is not serologic cross-matching and may be used only in case when the recipient/patient has no anti-erythrocyte antibodies wherein the patient must have a twice determined blood type [2]. There are 3 ways for the second, confirmatory determination of $\mathrm{ABO}$ blood group, namely: 1) checking the patient's blood group from medical documentation, 2) re-determination of blood group from an existing sample and 3) re-determination of blood group from a new blood sample.

Serological cross-matching can be performed in saline immediate spin crossmatch (IS-XM) and with anti-human globulin serum XM (AHG-XM). This test involves adding the patient's plasma to erythrocytes from a unit of blood. IS-XM was incubated briefly at room temperature and $\mathrm{AHG}-\mathrm{XM}$ at $37^{\circ} \mathrm{C}$, centrifuged, and the agglutination reaction was read [2]. The authors present consumables when performing serological cross-matching in order to obtain compatible blood for transfusion and display pharmaco-economic parameters that participate in the selection of an adequate unit of blood for transfusion for a particular patient.

A number of indices are used to determine the efficiency of blood ordering and utilization system [3]. Boral Henry was the first who suggested the use of cross-matching to transfusion ratio (CTR) 1975 [4]. CTR ratio is used for evaluation of blood transfusion practice. Ideally this ratio should be 1 but it is considered efficient if $<2.5$. CTR represents the ratio of the number of performed crossmatches (XM) and the number of transfused units of Red blood cells (RBC). This ratio is used as an index of the efficiency of blood ordering practice.

CTR = No. of units cross-matched / No. of units transfused
The probability of a transfusion for a given procedure is denoted by $\% \mathrm{~T}$ and was suggested by Mead and coworkers in 1980 [5]. A value of $30 \%$ and above has been suggested as appropriate $[5,6]$. The $\% \mathrm{~T}$ is calculated from the following equation:

\section{$\% \mathrm{~T}=$ No. of patients transfused $\mathrm{x} 100$ / No.} of patients cross-matched

The average number of units used per patient cross-matched is indicated by the transfusion index (TI) and signifies the appropriateness of number of units cross-matched. A value of 0.5 or more is indicative of efficient blood usage [6,7].

\section{TI $=$ No.of units transfused $/$ No. of patients cross-matched}

The number of units used per transfused patient $(\mathrm{Ti})$ is calculated from the following equation:

\section{$\mathrm{Ti}=$ No. of units transfused / No. of patients transfused}

The index which includes all other mentioned is Blood Ordering Quotient (BOQ) [3]. A value of 1.5 or less $(<1.5)$ is indicative of efficient blood usage. It is calculated from the following equation:

BOQ $=($ No. of units cross-matched $/$ No. of patents cross-matched) / (No. of units transfused / No. of patients transfused)

Unnecessary ordering of blood for surgical patients can be reduced without having any detrimental effect on the quality of patient outcome. Use of blood conservation policies such as the Maximal Surgical Blood Order Schedule (MSBOS) has succeeded in limiting unnecessary transfusion practices [8]. MSBOS with value of $1.5 \times \mathrm{TI}$ estimates the amount of blood that will be needed for the individual procedure. This is a criterion developed from institutional usage statistics providing a figure for the number of units to be cross-matched for any given surgical procedure [9].

Determination of $\mathrm{ABO}$ blood group and $\mathrm{Rh}$ type, and screens for clinically significant alloantibodies is denoted as type and 


\begin{tabular}{|c|c|c|}
\hline Data & 2010 & 2019 \\
\hline Total number of hospitalized patients & 15475 & 16897 \\
\hline $\begin{array}{l}\text { Interventions without cross-match (cerclage, hysteroscopy, polypectomy } \\
\text { with hysteroscopy, loop excision, loop conization) }\end{array}$ & 0 & 1952 \\
\hline Number of performed crossmatches & 9820 & 8344 \\
\hline Number of patients crossmatched & 7748 & 7436 \\
\hline Number of transfused RBC units & 3243 & 1867 \\
\hline Number of transfused patients & 2638 & 1265 \\
\hline Number of crossmatches per hospitalized patient & 0,63 & 0,49 \\
\hline Number of blood transfused RBC units per hospitalized patient & 0,21 & 0,11 \\
\hline
\end{tabular}

Table 1. Comparative oneyear blood consumption $(2010$ vs 2019) before and after introduction of T\&S system and restrictive policy of blood consumption screen (T\&S). T\&S upon admission is sufficient for the majority of the patients. In the surgeries, which have insignificant blood loss, only T\&S of the patient should be done and cross-matching can be avoided which can not only be rational and cost effective but also reduces the time lost in waiting for surgery.

However, one must confirm the availability of blood for emergency before starting the surgery [7]. Many studies [3,10] have shown that blood is generally over ordered and the implementation of MSBOS and the introduction of T\&S procedure have led to a safe, effective, and economic solution to ordering of blood.

\section{AIM}

Comparison of pharmaco-economic effect using transfusion indices on the number of performed cross-matches and the amount of packed red blood cells issued.

\section{MATERIAL AND METHODS}

In this paper, the authors present the results of a phase 4 academic retrospective-prospective study conducted at the Clinic for Gynecology and Obstetrics of the University Clinical Center of Serbia (KGA UKCS). The comparison was made between the year 2010 before the introduction of the Type and Screen (T\&S) System and the year 2019 when the T\&S System and restrictive policy in transfusion practice, were introduced. T\&S System was introduced for the following surgical interventions in gynecology and obstetrics: cerclage, hysteroscopy, polypectomy hysteroscopy, loop excision, loop conization. Data for 2010 were collected from written transfusion protocols of the clinic, and for 2019 were obtained from the hospital information system (Heliant) and written

\begin{tabular}{|l|c|c|c|}
\hline Indexes & $\begin{array}{c}\text { Profitability } \\
\text { limits }\end{array}$ & 2010 & 2019 \\
\hline CTR & $<2.5$ & 3.03 & 4.47 \\
\hline$\% T$ & $>30 \%$ & $34 \%$ & $17 \%$ \\
\hline $\mathrm{TI}$ & $>0.5$ & 0.42 & 0.25 \\
\hline $\mathrm{Ti}$ & $>1$ & 1.23 & 1.48 \\
\hline BOQ & $<1.5$ & 1.03 & 0.76 \\
\hline
\end{tabular}

\begin{tabular}{|c|c|c|}
\hline Data & 2010 & 2019 \\
\hline $\begin{array}{l}\text { Number of performed } \\
\text { cross-matches }\end{array}$ & 9820 & 8344 \\
\hline $\begin{array}{l}\text { Number of saved } \\
\text { cross-matches }\end{array}$ & 0 & 1952 \\
\hline
\end{tabular}

transfusion protocols.

The difference between two groups of data was examine with Chi-square test and Fisher exact test, with the reliability level set at $\mathrm{p}<0.05$.

\section{RESULTS}

The consumption of packed red blood cells was analyzed in relation to the requirements for cross-match before and after the introduction of the T\&S system and restrictive policy in transfusion practice, at the Clinic for Gynecology and Obstetrics UCCS (Table 1).

The number of performed crossmatches for 2019 as recorded in the crossmatch protocol was 8344 , and the number of patients was 7436, with CTR 4.47. In 2019. 1867 units of RBC were dispensed at 1265 patients. The index $\% \mathrm{~T}$ was $17 \%$ and TI was 0.25 . The average number of transfused RBC units per transfused patient ( $\mathrm{Ti}$ ) was 1.48 .

According to CTR, \% T and TI in 2019 our results indicate inefficient utilization of ordered blood, but decline in trans-
Table 2. Transfusion indexes one-year blood consumption (2010 vs 2019) before and after introduction of T\&S system and restrictive policy of blood consumption

Table 3. The number of performed cross-matches in relation to the number of saved crossmatches 
fused RBC units from 3243 to 1867 indicates an improvement in terms of the application of restrictive indication policy (Table 1 , Table 2 ).

CTR, TI and \% $\mathrm{T}$ can be used in the evaluation of blood consumption, but the BOQ index proved to be the best, which is in line with our laboratory and professional policy, which resulted in significant savings in the number of cross-matches and the number of blood units consumed (Table 1, Table 2).

With the introduction of the T\&S system, the number of cross-matches was reduced from 0.63 to 0.49 and the number of blood units was reduced from 0.21 to 0.11 per hospitalized patient, which at the level of one clinic represents a significant pharmaco-economic contribution of approximately $50 \%$.

Contrary, after the introduction of the T\&S approach, CTR was increased.

Statistically highly significant difference between the number of transfused and non-transfused patients in 2010 and 2019 $(\chi 2=696,26 ; \mathrm{df}=1 ; \mathrm{p}<0.01)$.

Chi-square test demonstrated statistically highly significant difference between the number of patients with cross-match and without cross-match $(\chi 2=119,11 ; \mathrm{df}=1$; $\mathrm{p}<0.01$ ) (Table 3).

\section{DISCUSSION}

Hospital blood bank tasks are defined in 210 of 282 steps, such as: Blood transport, records of entry, storage at $+4^{\circ} \mathrm{C},-30^{\circ} \mathrm{C},-80^{\circ} \mathrm{C}$, samples receipt and control, pre-transfusion testing (KGx2 +IR+DAT+IS), macroscopic examination of the unit, issuance of the component etc [11]. Based on the CTR of elective patients, many authors report inefficient utilization of ordered blood [12,13,14,15].

The introduction of T\&S methods means savings not only on performing XM but also on blood type confirmation [2].

The indexes (CTR, \%t, TI) followed in 2010 showed the necessity for introducing rationalization in blood requisition and consumption.

In our study, after processing $T \& S$ in ordering of blood and introducing a policy of restrictive use of blood, the indices (CTR, \% $\mathrm{T}, \mathrm{TI}$ ) failed to improve. Zewdie and collaborators found that the worst indices were from obstetrics unit with CTR ratio, $\% \mathrm{~T}$ and TI of $31.0,6.5 \%$, and 0.06 respectively $[12,13,14,15]$.

However, the BOQ as an overall as- sessment of the results after the introduction of the T\&S procedure indicated the accuracy of the decision, visible through a highly significant reduction in the consumption of total blood and per hospitalized patient. This lesson is clinically significant because it indicates the need for a longer and more thorough analysis of pharmaco-economics and clinically significant activities of transfusiologists [3]. Consequently, the biological blood wastage is reduced making the expenses smaller [16].

The indices themselves represent only a punctuation guideline in the validation of clinical transfusion results to achieve the overall targeted result. When reaching the conclusion it is necessary to include BOQ and monitoring over a longer period.

Despite the increased CTR after the introduction of the T\&S approach in our study, the increase in CTR does not mean a deterioration in blood requirements but an improvement in terms of the application of restrictive indication policies in accordance with national and international guidelines $[17,18,19]$.

The authors proved the importance of using the T\&S principle because the statistics clearly indicated a significant reduction in the number of cross-matches and a reduction in blood consumption despite the increased number of hospitalized patients.

The limitation of our study is the short time of monitoring and application only in gynecology and obstetrics. The authors, regardless of the limitations of the study, support the need for longer time monitoring, in order to show the effect of reducing blood demand through transfusion indices for assessing the effectiveness of the applied modules. This saves money, time, blood volume, protects staff from BURN OUT syndrome and provides the patient with a sufficient standard and enables the care of a larger number of patients $[20,21,22]$.

The objection to this procedure is the complexity of the steps and the large number of numerical values necessary to make a decision for the pros and cons of introducing the index, which additionally burdens the work of clinical transfusion services. However, the authors believe that the introduction of the indexes as a Parameter for monitoring the efficiency of transfusion should become part of routine work.

An increase in average blood consumption per transfused patient indicates better triage of patients regarding the indication 
for transfusion, which is clinically most important. This experience from clinical practice can be an important indicator for the national blood establishment for planning a national blood program.

\section{CONCLUSION}

The authors have concluded that the introduction of validation in blood transfusion indirectly draws the attention of prescribing physicians to take into account the significance of blood therapy.

The effects of the introduction of the T\&S method and restrictive transfusion policy are savings in blood consumption, decreased number of patients tested, a significant reduction in used blood units, and the number of performed cross-matches, despite the increased number of patients.

\section{CONFLICT OF INTEREST}

All authors declare no conflict of interest.

\section{REFERENCES}

1. World Health Organisation. Global Status Report on Blood Safety and Availability. 2017. Licence: CC BY-NC-SA 3.0 IGO https://apps.who.int/iris/ bitstream/handle/10665/254987/9789241565431eng.pdf

2. Jeffus S, Wehrli G. Blood Banking and Transfusion Medicine for the Apheresis Medicine Practitioner, J. Clin. Apheresis 2012;27(3):160-7. doi:10.1002/ jca21226

3. Vibhute M, Kamath SK, Shetty A. Blood utilisation in elective general surgery cases: requirements, ordering and transfusion practices. J Postgrad Med. 2000;46:13-17. PMID:10855071

4. Belayneh T, Messele G, Abdissa Z, Tegene B. Blood requisition and utilization practice in surgical patients at university of gondar hospital, northwest ethiopia. J Blood Transfus. 2013;2013:758910. doi: 10.1155/2013/758910. PMID: 24369525; PMCID: PMC3863566.

5. Mead JH, Anthony CD, M. Sattler M. Hemotherapy in elective surgery. An incidence report, review of the literature, and alternatives for guideline appraisal. American Journal of Clinical Pathology, 1980;74(2):223-227. doi: 10.1093/ajcp/74.2.223

6. Ho O, Bo B. Blood utilization in elective surgical procedures in Ilorin. Tropical Journal of Health Sciences, 2006;13(1):15-17. doi: 10.4314/tjhc. v13i1.36702

7. Friedman BA, Oberman HA, Chadwick AR, King- don KI. The maximum surgical blood order schedule and surgical blood use in the United States, Transfusion, 1976;16(4):380-387. doi:10.1046/j.15372995.1976.16476247063.x

8. Murphy WG, Phillips P, Gray A. Blood use for surgical patients: a study of Scottish hospital transfusion practices. Journal of the Royal College of Surgeons of Edinburgh,1995;40(1):10-13. PMID: 7738887

9. Dodsworth H, Dudley HAF. Increased efficiency of transfusion practice in routine surgery using preoperative antibody screening and selective ordering with an abbreviated cross-match, British Journal of Surgery, 1985;72(2):102-104. doi.org/10.1002/ bjs. 1800720210

10. Mujeeb SA. An audit of blood crossmatch ordering practices at the Aga Khan University Hospital: first step towards a maximum surgical blood ordering schedule (MSBOS). Journal of the Pakistan Medical Association, 2001; 51(10):379-380.

11. Linden JV, Wagner K, Voytovich AE, Sheehan J. Transfusion errors in New York State: an analysis of 10 years' experience. Transfusion 2000; 40(10):12071213. doi:10.1046/j.1537-2995.2000.40101207.x.

12. Zewdie, K., Genetu, A., Mekonnen, Y. Worku T, Sahlu A, Gulilalt D. Efficiency of blood utilization in elective surgical patients. BMC Health Serv Res 2019;19: 804. doi.org/10.1186/s12913-019-4584-1

13. Murugesan $M$, Subbiah SP. Blood requisition and utilization practice in obstetric patients at tertiary care center from South India: A descriptive study. Journal of Applied Hematology 2019;9(4):131-135. doi:10.4103/joah.joah_42_18

14. Alghamdi S, Gonzalez B, Howard L, Zeichner S, LaPietra A, Rosen G, Garcia G, Lamelas J, Goldszer R. Reducing blood utilization by implementation of a type-and-screen transfusion policy. A single-institution experience. Am J Clin Pathol. 2014;141(6):892-5. doi: 10.1309/AJCPX69VENS KOTYW.

15. Neb H, Zacharowski K, Meybohm P. Strategies to reduce blood product utilization in obstetric practice. Curr Opin in Anesthesiol. 2017;30:294-299. doi:10.1097/aco. 0000000000000463

16. Collins RA, Wisniewski MK, Waters JH, Triulzi DJ, Yazer MH. Effectiveness of multiple initiatives to reduce blood component wastage. Am J Clin Pathol. 2015;143:329-335. doi:10.1309/AJCP42WMHSSTPHXI

17. Republička stručna komisija za transfuziologiju, Transfuzija eritrocita u lečenju anemija, Nacionalni Vodič, Ministarstvo zdravlja Republike Srbije, Medicinski fakultet Univerziteta u Beogradu CIBID, Beograd 2005. / Republic Expert Commission for Transfusiology, Erythrocyte Transfusion in the Treatment of Anemia, National Guide, Ministry of Health of the Republic of Serbia, Faculty of Medicine, University of Belgrade CIBID, Belgrade 2005. On Serbian.

18. Muñoz M, Peña-Rosas JP, Robinson S, Milman 
N, Holzgreve W, Breymann C, Goffinet F, Nizard J, Christory F, Samama CM, Hardy JF. Patient blood management in obstetrics: management of anaemia and haematinic deficiencies in pregnancy and in the post-partum period: NATA consensus statement. Transfus Med. 2018;28(1):22-39. doi:10.1111/ tme.12443.

19. WOMAN Trial,. The Lancet. 2017;389(10084)

20. Bukumirović Aleksandra M., Totić-Poznanović Sanja D., Marković-Denić Ljiljana N., Bukumirić Zoran M., Vlačić Aleksandra N., Radak Vladimir S., Lasica Ratko M., Šijački Ana D. Burnout syndrome at work by doctors employed at Emergency Center of Clinical center of Serbia. Hospital Pharmacology - International Multidisciplinary Journal, 2018;5(2):647-653. doi:10.5937/hpimj1802647B

21. Živanović DB, Javorac JM, Knežević JD. Burnout Syndrome Among Intensive Care Nurses. Hospital Pharmacology. 2019; 6(3):848-856 UDC: 613.86:616-051; 159.944.4.072. doi:10.5937/hpimj1903848Z

22. Petrov A, Gatchev E, Damyanov D, Korukov B, Kolev E. Interdisciplinary approach in development and implementation of local guideline for surgical antimicrobial prophylaxis: Experience of the university hospital 'Tsaritsa Yoanna - ISUL', Sofia, Bulgaria. Hospital Pharmacology - International Multidisciplinary Journal, 2014;1(1):15-21. doi:10.5937/ hpimj1401015P 


\title{
Efekti uvođenja Type\&Screen sistema na racionalno korišćenje transfuzije
}

\author{
Aleksandar O. Stefanović ${ }^{1}$, Emina S. Čolak ${ }^{1}$, Gordana D. Stanojević ${ }^{2}$ \\ Ljubinka I. Nikolić ${ }^{1}$ \\ ${ }^{1}$ Univerzitetski Klinički Centar Srbije, Beograd, Srbija \\ ${ }^{2}$ Dom zdravlje Zvezdara, Beograd, Srbija
}

\section{KRATAK SADRŽAJ}

Uvod: Postoji potreba za racionalizacijom testiranja i potrošnje krvi u transfuziji. Određivanje krvne grupe u $\mathrm{ABO}$ i Rh sistemu i skrining na klinički značajna antitela naziva se type\&screen (T\&S). Type\&screen je najčešće dovoljan za pacijente pri prijemu na bolničko lečenje.

Cilj: Komparacija efekata uvođenja transfuzioloških indeksa na broj interreakcija i broj potrošenih jedinica eritrocita.

Metodologija: Autori poređuju 2010. godinu pre uvođenja transfuziološkog pristupa type\&screen i 2019 godinu nakon uvođenja transfuziološkog pristupa type\&screen. Za 2010. godinu korišćeni su podaci iz transfuzioloških protokola a za 2019. iz bolničkog informacionog sistema (Heliant) i transfuzioloških protokola. Razlika uzmeđu grupa je testirana Hi-kvadrat testom i Fišerovim testom. Kao granica značajnosti korišćena je vrednost $p<0.05$.

Rezultati: Uvođenjem T\&S sistema broj interreakcija se, po hospitalizovanom pacijentu, smanjio sa 0.63 na $0.49(p<0.05)$, a broj izdatih jedinica eritrocita sa 0.21 na $0.11(p<0.01)$ što je na nivou jedne klinike približno $50 \%$ smanjenje troškova. U našoj studiji nakon uvođenja T\&S sistena nije došlo do poboljšanja transfuziološih indeksa (CTR, \%T, TI). Uprkos nepoboljšanim transfuzijskim indeksima, primena restriktivne indikacione politike u transfuziji u skladu sa nacionalnim i svetskim vodičima dovela je do značajnog smanjenja potrošnje krvi sa 3243 na 1867 jedinica eritrocita. Vrednost $B O Q$ je jedini sumarni pokazatelj rezultata uvođenja T\&S sistema i on je u našem istraživanju pokazao značajno smanjenje sa 1.03 na 0.76 .

Zaključak: Autori zaključuju da uvođenje validacije T\&S sistemom u kliničku transfuziju skreće pažnju ordinirajućim lekarima na značaj odgovornosti u indikacijama i primeni krvi. Uvođenjem T\&S metode kao i restriktivnih indikacija za primenu krvi redukovana je potrošnja krvi, smanjen broj interreakcija uprkos povećanom broju pacijenata.

Ključne reči: transfuzijski indeksi, Interreakcija, krv, krvna grupa, BOQ, CTR, TI 